\title{
Government Loan and Guarantee Programs
}

\author{
JOEL FRIED
}

T

HE U.S. government is involved heavily in providing credit assistance to the private sector. From 1971 to 1981, the total amount of federally assisted credit outstanding jumped from $\$ 217$ billion to $\$ 678$ billion, an increase of over 200 percent. ${ }^{1}$ Moreover, government direct and guaranteed loans constituted almost 12.5 percent of the total funds advanced, direct ly or indirectly, to the non-federal sector over the period 1972-81. In 1980 and 1981, the proportion of new funds loaned to the non-federal sector in the form of a government direct loan or guarantee rose to 17 percent. $^{2}$

This article examines the consequences of direct and guaranteed loan programs on interest rates and aggre* gate demand. The analysis focuses on shifts in the supply and demand schedules for alternative sources of credit affected by each type of program. The results indicate, under fairly standard assumptions, that an increase in government direct loan programs accompanied by an equal decrease in government-guaranteed loan programs will decrease loan rates to borrowers who are ineligible for credit assistance. This shift in loan assistance also will increase the rate of interest on

Joel Fried is an associate professor of economics at the University of Western Ontario. This article was written while Professor Fried was a visiting scholar at the Federal Reserte Bank of St. Louis. Thomas $H$. Gregory provided research assistance.

'See The Budget of the United States Government, 1983, Special Analysis $F$, Federal Credit Programs (Washington, D.C. 1982). This credit assistance consists of direct government loans, loan guarantees and loans by government-sponsored enterprises.

${ }^{2}$ These data are calculated from Ibicl., table F-1, p. 6. It excludes new equity finaucing. government debt, and will increase the demand price of capital and level of aggregate demand.

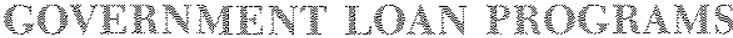 AND PORTHOLO CDO CL}

There are two major mechanisms by which the government provides credit to private individuals through capital markets: guaranteed loans and direct loans. ${ }^{3} \mathrm{In}$ the former, the government, having designated the potential recipients, guarantees loans made to this group by private financial intermediaries (hereafter referred to as banks) against any default. In a competitive banking environment, banks will pass on the economic value of the guarantee to the borrower. As a result, the borrower obtains the loan at a lower rate than the bank would have charged without the government guarantee. ${ }^{*}$

In the case of direct loans, a government agency acts as an intermediary in place of banks; it issues loans directly to the targeted group, obtaining the necessary

\footnotetext{
This does not exhaust the forms of govemment eapital market intervention. Other prowrams affecting capital markets that have come under the scruteny of the Treasury in recent years include lending by government-sponsored enterprises and tax exemptions for interest income on some types of loans. These are not considered in this paper.

This slabsty need not be restricted to the actuarialy fais value of the insurance. The government also could charge the banks a fot for the provision of the insurance or could provide a cash subsidy in addition to the guarantee if for some reason, it wished the effective subsidy rate to be diferent from the expected defult rate.
} 


\section{Table 1 \\ Direct Loan Transactions of the Federal Government: 1982 Fiscal Year (millions of dollars)}

\begin{tabular}{|c|c|c|}
\hline & Net oulays & Outstandings \\
\hline \multicolumn{3}{|l|}{ On Budgot Mgencles } \\
\hline funds aporopriated lo he President & 8777 & 6,17992 \\
\hline 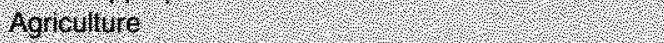 & V. 6.164 & 131,06 \\
\hline Gominerce & $\sqrt{104}$ & (1) 89 \\
\hline Eovertion & 641 & 9.859 \\
\hline Enegy & & 13 \\
\hline reall progroms & 20 & 921 \\
\hline Housing ano Urban Developrient & 351 & 13.216 \\
\hline nerior? & (1) & 441 \\
\hline Transportation & 8066 & 1.4003 \\
\hline Veterans Administration & 228 & 3,868 \\
\hline Loans to the Destriet of Colunibia & 17 & 1689 \\
\hline Expon Iripor Bank & 776 & 16,565 \\
\hline Federa) Beposil insurance Corporation & 274 & 705 \\
\hline Federal Hone Loan Bank Board & 846 & 758 \\
\hline National Gredif Union Adinistration & 34 & 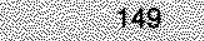 \\
\hline small Eusiness Admitistration & 22 & 9.160 \\
\hline Teninessee Villor Autrorly & 20. 69 & 2.267 \\
\hline Other agenges and prograns & $(224$ & $\sqrt{1091}$ \\
\hline Sublolar on buggel agencies & 9.107 & 100220 \\
\hline Oribudget rederal Entiles & & \\
\hline Rural flect tication and Telephone Fevolving r und & $6+130$ & 6.9774 \\
\hline hutal relephone Bank? ? ? ? ?? ? & 102 & 1,173 \\
\hline Federal Fnanong Bant (IFB) & $1 4 \longdiv { 1 5 5 }$ & 96,519 \\
\hline 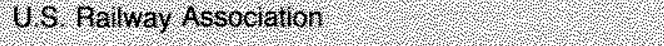 & 42 & 3.123 \\
\hline Yे. Sublotal, of budget tederat enities & 14,345 & 107,586 \\
\hline Total, net dired loars & $\$ 23.452$ & $\$ 201808$ \\
\hline
\end{tabular}

funds from the capital markets by issuing Treasury securities. Because government securities are used to raise the funds, the interest cost will be lower than on funds raised by private institutions. If the government intermediary passes on this reduction, the borrower will obtain a subsidized rate of interest on his loan. ${ }^{5}$

\footnotetext{
The subsidy here refers to the difference between the rate of interest a borrower would pay if the loan were obtaned from a bank and the rate he would pay under either the loan guarantee or direct foan programs of the goverment. This may not comespond to the subsidy as viewed by the taxpaver; that is, the cost of the loan less the rate of nuterest paicl on the lom. Rongh estinates of the sulusidies involved in the various government loan and guarantee programs are presented in Special Analysis $F$, Federal Credit Programs, I982. See, especially, tables $\mathrm{F}-11 \mathrm{~A}$ and F-11B
}

Tables 1 and 2 present the various direct loan and guarantee programs that existed in the 1982 fiscal year. As the tables show, virtually every sector of the economy is covered by some type of program, and assistance to some sectors takes the form of both direct loans and guaranteed loans. For instance, of the $\$ 9,943$ million loans and guarantees outstanding in 1982 for the Farmers Home Administration's program for rumal development, $\$ 153$ million was on-budget direct loans, $\$ 3,387$ million was off-budget direct loans through the Federal Finance Bank (FFB) and \$6,403 million was provided through government guarantees. Indeed, the FFB holdings of loans guaranteed by a variety of on- and off-budget agencies provides an especially convenient mechanism to convert loan guarantees into direct loans. The FFB simply pur- 
Table 2

Guaranteed Loan Transactions of the Federal Government: 1982 Fiscal Year (millions of dollars)

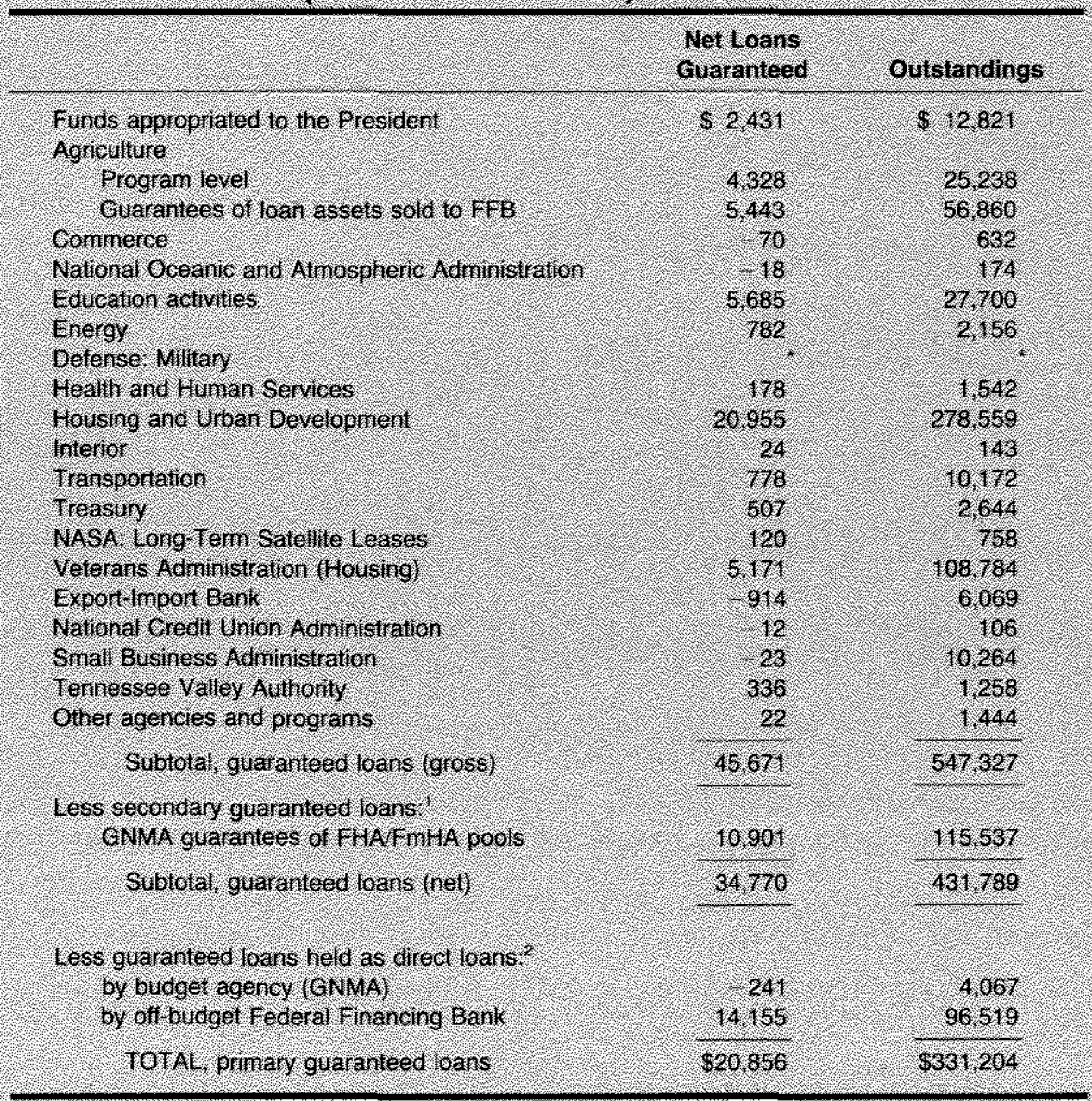

$5500,0000010 s 8$

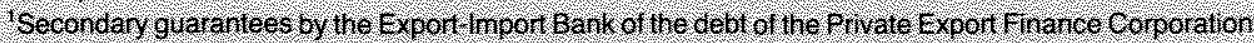
have nor been estimared and are exculed from the table

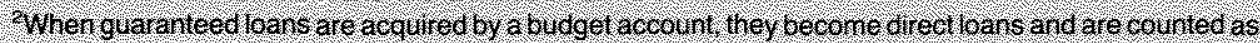
such in table 1. They are, therefore, deducted tron the totais in this table:

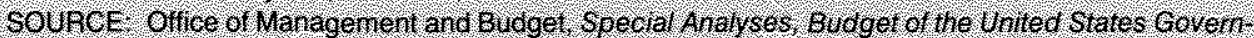

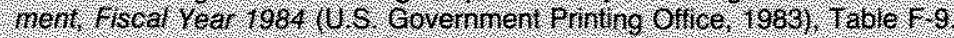

chases the guaranteed loans that would otherwise have been sold to private banks. ${ }^{6}$

"It also should be noted that the distinction between "on-budget" and "off-budget" direct loans is really only an accounting distinction. Net new direct loans issued by on-badget agencies are treated as part of the budget: an increase of $\$ 1$ million in these loans shows up as an increase of $\$ 1$ million in the budget deficit. An increase of the sane amount in off budget FFB direct loans would not increase the deficit. Both will do precisely the same thing to the government debt, however, namely increase it by $\$ 1$ millon. In the case of
Government loans and guarantees embrace a variety of programs, none of which is of specific interest here. Thus, the subsequent analysis assumes that recipients

on-budget direct loans, the funds are allocated by the Treasury directly to the agency; in the case of FFB direct lending, the FFB draws on its line of eredit at the Treasury and the Treasury then issues debt to provide the ets $B$ with the funds. This accounting convention, while perhaps important for congressional control, has no operational meaning for the issues considered here and is ignored. 
of government direct loans or guarantees are drawn randomly from the general population. Our focus is on the effect of moving a preselected group of individuals from one type of program to the other, without regard to the specific program itself. ${ }^{7}$

The principal difference between the government direct loan and guarantee programs lies in the portfolios that households and banks must hold as a result of these programs. For a given level of total government credit provided, an increase in the number of direct loans granted will increase the amount of government securities that must be held by either banks or households. Therefore, a general model of portfolio choice is necessary to trace the effects of differential changes in the two programs. In this article, the analysis is derived from the implications of a formal model based on the work of James Tobin and detalled elsewhere. ${ }^{8}$

To present the model, the credit market is first described for the case in which no government credit programs exist; then the impacts of introducing first a guarantee program and then a direct loan program are examined. Having examined the impact of each program separately, the differential impact of the two programs on interest rates and aggregate demand can then be assessed.

\section{THI MARE STOC OY CREVIT}

Suppose there are no government direct loan or guarantee programs. The market for credit then is characterized in figure $1 . D_{0}$ describes the demand for loans by the private sector and is a function not only of the loan rate, $R_{9}$, but also of rates of return on capital goods and on government securities. An increase in the loan rate decreases the quantity of credit de-

\footnotetext{
The choice of program and recipient is, however, important in considering the impact of increases in total federal credit assistance. The answer to the question of whether such increases would increase the welfare of society hinges on whether the new assistance decreased differences in the social and private marginal benelits of credit to the recipient. The assumption that recipients are chosen randomly would be inappropriate for such an analysis. Therefore, this question is not addressed in this article.

"See Joel Fried, "Government Direct Loaus and Loan Guarantee Programs; A Formal Analysis," Feteral Reserve Bank of St. Louis Working Paper \#83017, October 1983. This analysis modifies the framework presented by James Tobin, "A General Equilibriam Approad to Monetary Theory," Journal of Money, Credit and Banking (February 1969), pp. 15-29, to incorporate the two types of government credit assistance.
}

Figure 1

The Loan Market, Excluding Goverantent Loan Programs

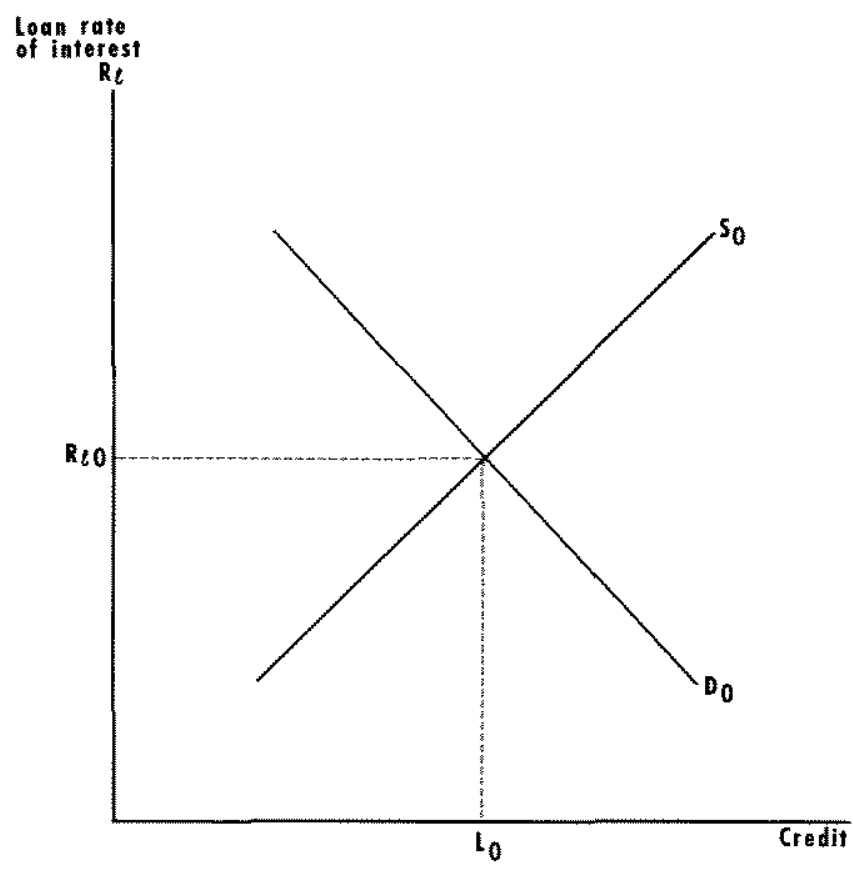

manded; increases in rates of return on other assets shift the demand curve out. ${ }^{9}$

The credit supply curve of banks is described by the upward sloping line $S_{0}$. By assumption, it is positively sloped to reflect the increasing marginal costs of lending. These costs consist of the operating costs of the bank loan department and the cost of obtaining funds to lend, either by attracting more deposits or by selling government securities from the bank's portfolio. ${ }^{10}$ An increase in the rate of return on any other asset that the bank could hold would shift the supply curve for credit up, as would an increase in the rate of interest on deposits. As drawn in figure 1 , the equilibrium level of credit is $L_{0}$ and the equilibrium rate of interest on it is $\mathrm{R}_{90}$.

\footnotetext{
${ }^{9}$ In principle, at least, increases in the rate of return on any asset will increase the demand for credit as the houselold reshuffes its entire portfolio to take advantage of this higher return. In practice, it can be expected that increases in $\mathrm{R}_{\mathrm{k}}$ will alter credit demand more than would an equal increase in $R_{g}$ or $R_{d}$. This is because hotseholds generally do not borrow to purchase assets that yield pecuniary returns lower than the loan rate.

${ }^{10}$ The analysis in Fried, Government Direct Loans (see equation 1-3) supposes that govemment securities, like money, can be viewed as a "producer's good" that facilitates exchange activity. See also Joel Fried and Peter Howitt, "The Effects of Luflation on Real Interest Rates," American Economic Review (December 1983), pp. 968-80, for a more detailed presentation of this view.
} 


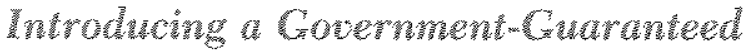 Loan Program}

Now suppose the government institutes a government guarantee program that is available only to a portion of the population. ${ }^{11}$ Figure 2 shows the consequences of this program in the credit market. For comparison, $\mathrm{D}_{0}$ and $\mathrm{S}_{0}$ are the same as in figure $1 . \mathrm{D}_{1}$ describes the demand for loanable funds by all potential borrowers who are not eligible for government guaranteed loans.

To establish the effects of the guarantee program, some assumptions about the relationship between the rate of interest on loans that do not have a government guarantee, $R_{9}$, and on those that do have the guarantee, $R_{g g}$, must be made. We shall assume that the government wants to provide preferred borrowers a fixed subsidy rate, $S$, per dollar of loan, and that the banking system is sufficiently competitive that, at the margin, the profit rates on guaranteed and nonguaranteed loans are equalized. ${ }^{12}$ Thus,

(1) $R_{g g}=R_{g}-S$

Under this assumption, changes in $S$ cause the total demand for credit, as a function of $R_{9}$, to shift; as $S$ is increased, individuals eligible for government-guaran" teed loans would increase their demand for credit at any given $R_{2}$. Thus, for a positive subsidy rate, credit demand would be greater than it otherwise would be without the guarantee program. $\mathrm{D}_{2}$ in figure 2 de-

\footnotetext{
${ }^{11}$ As mentioned earlier, it is supposed that those eligible for the government programs are chosen randomly from the population at large. This assumption is not meant to deny one rationale often given for government credit assistance programs, namely, that these are set up to provide funds to high-risk individuals and institutions. Rather, it is to clarify the exposition of the financing effects of the direct loan and guarantee programs, which is our primary concern. If this assumption is not made, then the loan supply schedule of banks would depend on how the favored group was chosen. If the government could identify the high-risk borrowers in the economy and provide them with guarantees or direct loans, then the supply curve of loans by banks to uninsured borrowers, ceteris paribus, would most likely shift ont with the establishment of the government programs.

${ }^{12}$ Suppose banks initially did not pass on these reduced costs to the borrower. Then, $\mathrm{D}_{0}$ would continue to describe the total demand for credit. Each bank, however, would have an incentive to offer a lower rate to insured borrowers or give loans to them in prefer. ence to uninsured borrowers. Over time, therefore, $R_{\mathrm{gg}}$ would be forced down relative to $R_{g}$. The competitive banking industry assumption says simply that, in equilibrium, relative rates are such that any individnal bank will be indifferent to offering the next loan to either an insured or an uninsured borrower.
}

Figure 2

The Loan Market, Including Government Guaranteed loans

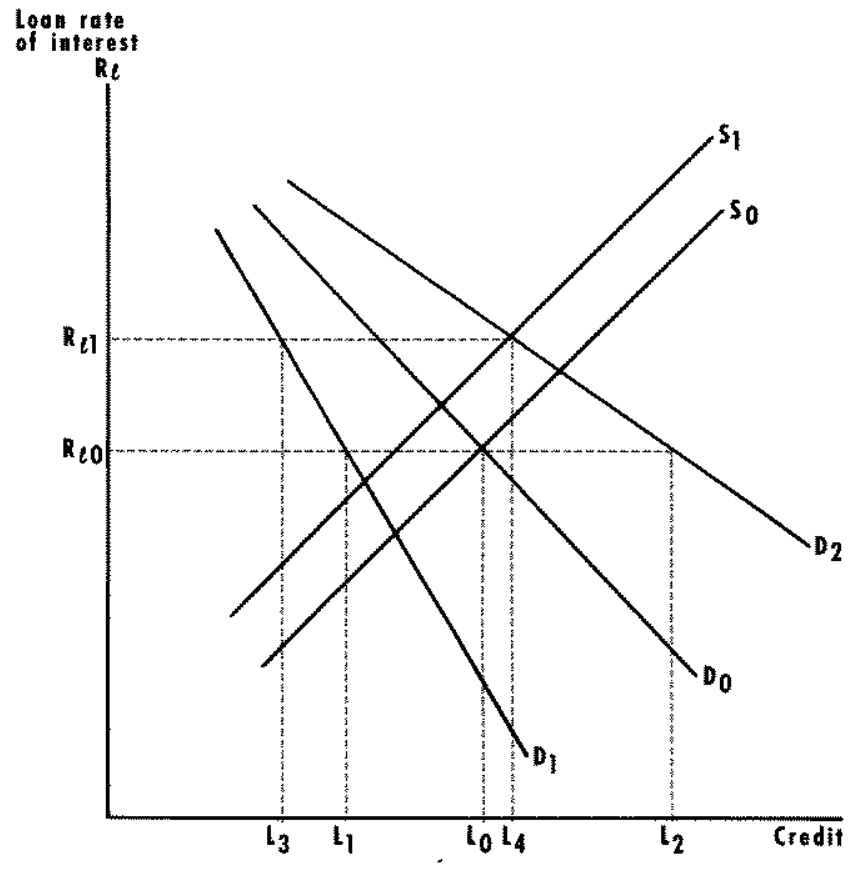

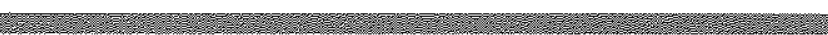

scribes this new demand curve for total credit with the introduction of the government guarantee program. At $\mathrm{R}_{g_{0}}$, there is now an excess demand for loans of the amount $\mathrm{L}_{2}-\mathrm{L}_{0}$. This puts pressure on $\mathrm{R}_{9}$ to rise. Furthermore, as banks issue more loans, they will sell government securities. Therefore, the rate of interest on these securities, $R_{g}$, increases. The increase in $R_{g}$ causes the credit supply curve to shift up, so that less credit will be supplied at any given $\mathrm{R}_{9}$. Finally, as individuals take out additional loans, they increase their demand for titles to capital goods, causing the rate of return on these assets, $R_{k}$, to fall. This reduces, in part, the demand for loans, but does not shift the demand schedule back to $\mathrm{D}_{0 .}{ }^{13}$

The new portfolio equilibrium will be at some new loan rate, $R_{91}$, greater than $R_{90}$, and will be characterized by a higher $R_{g}$ and lower $R_{k}$. Furthermore, if the credit market is stable, the equilibrium rate of interest on guaranteed loans, $R_{21}-S$, will be less than

\footnotetext{
${ }^{13}$ It is also the case that, from general portfolio considerations, the demand for credit will shift out as $R_{1}$ rises. For notational convenience, these demand curve shifts have been suppressed in figure 2 .
} 
$\mathrm{R}_{90} \cdot{ }^{14}$ At this new set of interest rates, there will be a total supply of credit of the amount $\mathrm{L}_{4}$, consisting of $\mathrm{L}_{3}$ non-guaranteed loans and $\mathrm{L}_{4}-\mathrm{L}_{3}$ governmentguaranteed loans. Loans to borrowers ineligible for government-guaranteed loans of the amount $L_{3}-L_{1}$ that would have been made at $R_{g_{0}}$ are no longer made.

The portfolio readjustment described above represents the initial response to the introduction of the government guarantee program. Because relative yields on financial instruments have been altered, the stocks that households wish to hold will change. This, in turn, will alter the allocation of flows over time. In particular, because the demand price for capital has increased ( $\mathbf{R}_{\mathrm{k}}$ has fallen), there is an increase in the demand for real capital, stimulating the production of these goods and increasing aggregate demand in general. ${ }^{15}$

The increase in aggregate demand can take the form of an increase in prices or real income. Suppose that real income begins to increase first, transiently rising above full-employment output. This increase generates increased savings to provide the real resources to accommodate the real investment.

Over time, however, the demands on real resources begin to be reflected in increased prices. These increases reduce real cash balances and real holdings of government securities by more than they otherwise would have been. In an attempt to maintain the real holdings of these assets, banks would decrease their supplies of credit, forcing loan rates up. The long-run equilibrium would then be characterized by a decline to full-employment real income, a higher price level and lower real supplies of monetary base and government interest-bearing debt. The distribution of loans

\footnotetext{
${ }^{14}$ To see this, note that the initial shock was an increase in loans supplied at any given $\boldsymbol{R}_{\mathbf{f}}$. If $\mathbf{R}_{91}-\mathbf{S} \geqslant \mathbf{R}_{\mathbf{q}_{0}}$, then demand by insured borrowers is less than $L_{0}-L_{7}$, and demand by uninsured borrowers is $L_{3}<L_{1}$. Thus, if $R_{91}-S \geqslant R_{90}$, an increase in the planned supply of loans causes a decrease in equilibrium loans supplied, implying an unstable equilibrium. For the purposes of this paper, we shall rule out unstable equilibria. See Mary Kay Plantes and David Small, "Macroeconomic Consequences of Federal Credit Activity," in Conferences on the Economics of Federal Credit Activity, Part II-Papers (Congressional Budget Office, 1981) and comments on it by George von Furstenberg, in Conference on the Economics of Federal Credit Activity, Past I-Proceedings for a more complex model that permits them.

${ }^{15}$ Over time, the subsidy on the government - guaranteed loans must also be paid. It is assumed here that lump-sum taxes are raised to pay for them, so that the subsidy itself represents a transfer from the population at large to recipients of government-guaranteed loans and, as such, does not represent a change in aggregate demand.
}

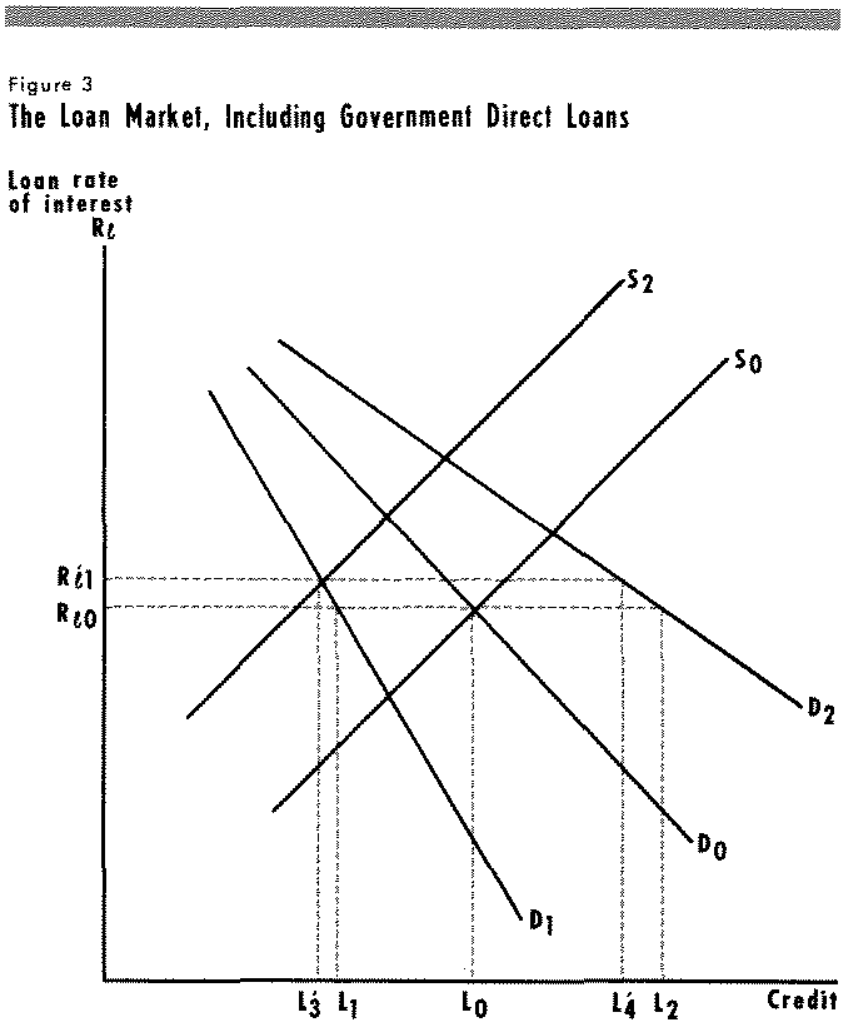

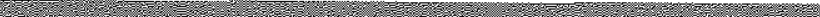

would be such that recipients of governmentguaranteed loans would have a greater command over resources at the expense of borrowers ineligible for guarantees and the population at large who pays for the subsidies in the program.

\section{Throducing a novernmen Direce Loan Program}

Now consider the consequences if the government initiates a direct loan program instead of a loan guarantee program. To facilitate the comparison, suppose the government again provides the same subsidy rate per dollar of loan, $S$, so that the interest rate on government direct loans, $R_{\mathrm{gg}}$, is

(2) $R_{g}=R_{q}-S$.

Further, suppose the same individuals are eligible for the government direct loans as were eligible for the loan guarantees. As figure 3 shows, under these assumptions, $D_{0}, D_{1}$ and $D_{2}$ are the same as in figure 2 except that the horizontal distance between $D_{1}$ and $D_{2}$ now describes the demand for government direct loans instead of guaranteed loans. $R_{90}$ and $L_{9}$ describe the bank loan rate and volume of credit before the introduction of the direct loan program. 
To examine the forces at work when the direct loan program is introduced, consider the demand and supply of credit at $\mathrm{R}_{90}$. First, there will be an excess supply of loans that the banks wish to issue of the amount $\mathrm{L}_{0}-\mathrm{L}_{1}$. This is because those customers who had taken out bank loans before, now find that their eligibility for direct govermment loans reduces their cost of credit. Consequently, they no longer demand bank loans at $R_{90}$. At $R_{90}$, however, banks would not want to alter their planned supply of credit; the decreased demand and unchanged supply mean an excess supply. Second, at $R_{90}$, the total demand for credit has increased to $\mathrm{L}_{2}$ from $\mathrm{L}_{0}$. To finance this demand for government direct loans, the government will issue government securities. Thus, there is also an excess supply of government securities. This causes $\boldsymbol{R}_{\mathrm{g}}$ to rise, shifting up the credit supply function of banks to, say, $\mathrm{S}_{2}$.

While $S_{2}$ is drawn such that $R_{9}$ rises in the new portfolio equilibrium, this need not be the case. At $R_{90}$, an increase in $R_{g}$ increases the opportunity cost of bank loans. This may or may not offset the cost decreases that accompany the reduction of the scale of bank loan operations to $L_{1}$ from $L_{0}$ : if it does offset these cost decreases, then $R_{Q}$ will rise; if it does not, $R_{q}$ will fall.

The impact on aggregate demand is qualitatively the same as occurs with an increase in guaranteed loans. There is an increase in the demand price of capital (a decrease in $R_{k}$ ), making it more profitable for firms to invest. This puts pressure on output and prices to increase. The increase in price, in turn, reduces real wealth, causing output to fall to its full-employment level. This causes loan rates to rise and the demand price of capital to fall. The real quantity of monetary base will be less than it was at the initial equilibrium.

\section{A Compensuted Change hin Cowernment-Guaraned and Dred Loans}

Columns 1 and 2 of table 3 describe the portfolio effects of both the guaranteed loan and direct loan programs. With the exception of the loan rate on uninsured bank loans, these results are identical. The question now to be addressed is: What are the consequences on interest rates and aggregate demand if the direct loan program is expanded and the guarantee program reduced, so that there is no change in the total number of individuals eligible for the government sub sidized rate of interest? In other words, does it matter whether a direct loan program is used instead of a loan

\section{Table 3}

The Portfolio Effects of Changes in Government Credit Programs on Interest Rates and Aggregate Demand

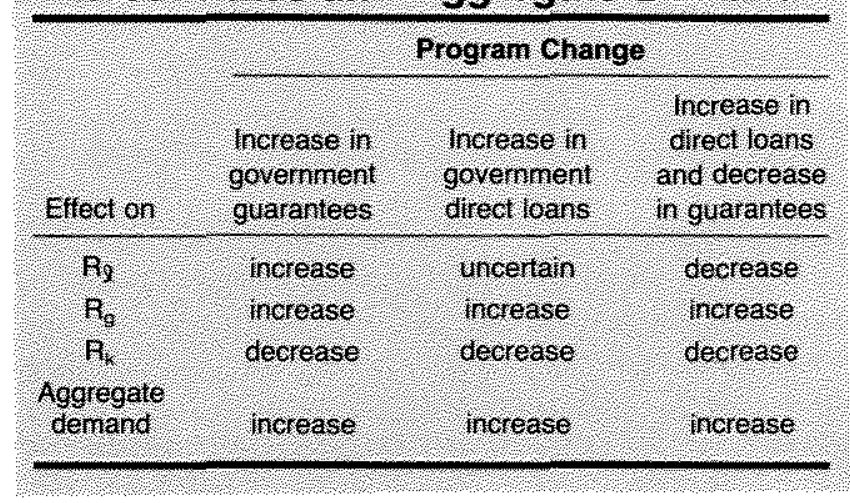

guarantee program with the same borrowing rate and the same eligibility requirements, and, if so, how ${ }^{16}$

To answer this question, suppose the government currently has both programs in operation. Further, suppose that the interest rate on direct government loans is equal to the net of subsidy rate, $R_{2}-S$, on govermment-guaranteed loans. Thus,

(3) $\mathbf{R}_{\mathbf{q}}=\mathbf{R}_{\mathrm{gg}}+\mathrm{S}=\mathbf{R}_{\mathrm{g} \boldsymbol{Q}}+\mathbf{S}$.

This ensures that potential recipients of either government program receive the same subsidized rate. The analysis can be followed in figure 4 , where $D_{1}^{*}$ describes the demand function for non-insured bank loans, $\mathrm{D}_{2}^{*}$ is the demand for total bank loans (govern-

\footnotetext{
"The results to this point can be explained intuitively by naking an analogy to government programs in the fielt of medical care. If more individuals become insured under, say, the Medicare program, the total demand for hospital care will increase. If beneficiaries of the program may use any private hospital, the cost of hospital care at these institutions will rise, crowding out some uninsured individuals, though not as many as the increased number of insured patients (or costs would not have increased). If, on the other hand, insured patients can receive subsidized care only if they go to certain specified government hospitals, as required say, by the Veterans Administration programs, demand at non-VA hospitals will fall, causing hospital costs there either to decrease (because of the lower utilization) or increase (because the demand for doctors will have increased catusing their salaries to rise at all hospitals). The Medicare program is similar to the ban guarantee program. The VA program is analogous to the direct loan program. Costs to the patients are analogous to the loan rates to borrowers wishing to parchase capital and the price of doctors services is an analog to the interest rate of government securities. The question now addressed in the text - substituting direct loans for guaranteed loans - in the health care analogy is the following: What is the effect on the cost of medical care if veterans' wives over age 65 were added to the VA program and not permitted to use the Medicare program?
} 
Figure 4

The Loan Markel, if Direct Loans Replace Gataranted Loans

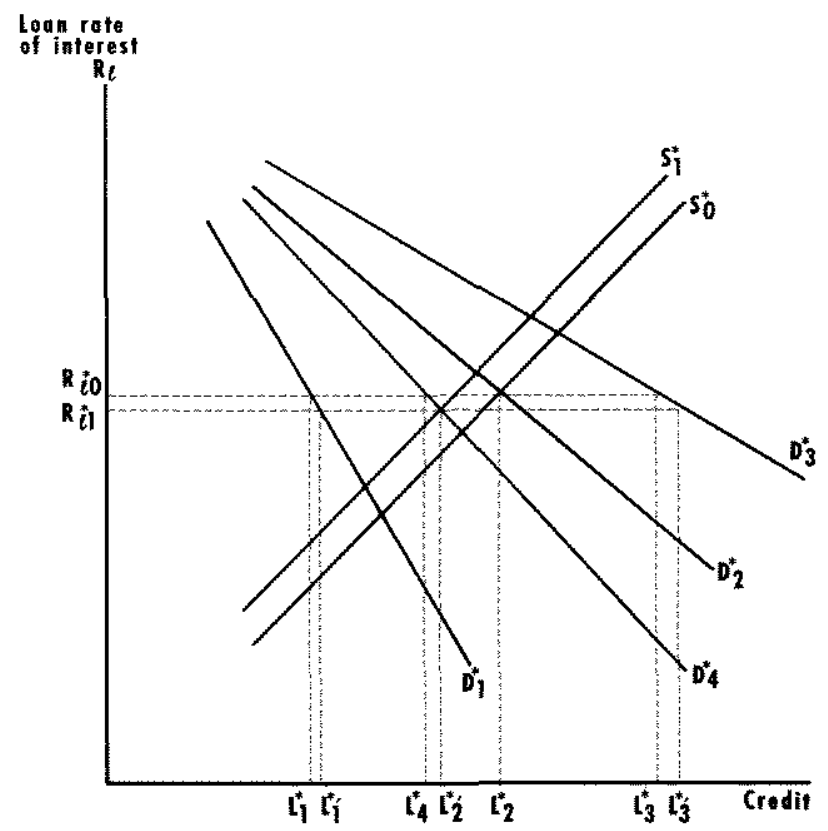

ment-guaranteed and non-guaranteed), and $\mathrm{D}_{3}^{*}$ is the total demand for credit under the pricing assumption made above. The initial equilibrium is at $\mathrm{R}_{90}^{*}$, with $\mathrm{L}_{1}^{*}$ non-guaranteed loans, $\mathrm{L}_{2}^{*}-\mathrm{L}_{1}^{*}$ government-guaranteed loans, and $\mathrm{L}_{3}^{*}-\mathrm{L}_{2}^{*}$ direct government loans.

Now suppose that the government changes its policies so that some individuals lose their eligibility for government-guaranteed loans, but are now eligible for government direct loans. This is described in figure 4 by a shift in the demand for total bank credit from $D_{2}^{*}$ to $\mathrm{D}_{4}^{*}$. Suppose initially that the loan rate remained at $\mathrm{R}_{90}^{*}$ and $\mathrm{R}_{\mathrm{g}}$ remained at its initial level. There would then be an excess supply of total bank loans of the amount $L_{2}^{*}-L_{4}^{*}$ and, because government direct loans are financed by issuing government securities, an excess supply of government securities of an equal amount.

The former puts pressure on $R_{2}$ to fall and the latter causes government security rates to rise until a new portfolio equilibrium is established. If the system is stable, then $R_{9}^{*}$ will fall, say, to $R_{q 1}^{*}$, and $R_{g}$ will rise above its initial rate. ${ }^{17}$ Because the total supply of

\footnotetext{
${ }^{17}$ An implication of this analysis is that an increase in the federal budget need not, ceteris paribus, cause loan rates to rise nor crowd out borrowing and investment by the private sector. This is
}

credit has increased, there will be an increase in the demand price for capital and in the level of aggregate demand. ${ }^{18}$ Therefore, the analysis suggests that the use of government direct loans increases aggregate demand more than government guaranteed loans that provided credit to the same individuals at the same rate of interest.

As a consequence of the increase in aggregate demand, either quantities or prices must rise to equilibrate the goods market. If prices rise, interest rates on loans and on titles to capital tend to rise as demands for these instruments decline with the decrease in real wealth. Because both investors and consumers face decreases in wealth from the price rise, these groups will reduce their (real) planned expenditures. It further seems reasonable to suppose that personal consumption will decrease, so that borrowers obtain an increased command over the flow of real resources. Thus, even with the price adjustment, the demand price of capital is greater than it was before the change in the program.

\section{GUMNAS}

This article has argued that government direct loan programs are more stimulative than government guarantee programs with identical amounts of credit assistance. ${ }^{19}$ The use of the direct loan program will

\footnotetext{
because direct loans by on-budget agencies are included in the budget deficit. Such direct loans could increase through a conpensated decrease in goverument guaranteed loans, in which case the analysis implies that private loan rates would fall. Even an uncompensated increase in direct loans by onmbudget agencies may cause an initial decrease in loan rates (see Fried, Government Direct Loans).

${ }^{18}$ In figure 4 , the fall in $R_{9}$ will, for a given $S$, lower $R_{g g}$ and $R_{g}$ and therefore increase the demand for direct and guaranteed loans. This explains only part of the increased demand. The same qualitative results also hold when the total subsidy $\left(L_{3}^{*}-L_{1}^{*}\right) S$, remains fixed. (The case of the fixed total subsidy is derived in Fried, Government Direct Loans.) The rise in $\mathrm{R}_{\mathrm{g}}$ causes individuals and banks to conserve on their cash balances and excess reserves. This permits a total expansion of credit as the yield on deposits is increased, increasing total bank deposits. The sufficient conditions for a compensated increase in government direct loans to be expansionary are that the demand for capital goods be more responsive to loan rates than to government security yields, and that the demand for the monetary base and deposits be more responsive to government security rates than to loan rates.

${ }^{19} \mathrm{Critical}$ to this result are the assumptions that government securities and guaranteed loans are not perfect substitutes for one another in bank portfolios, that guaranteed loans are closer substitutes to non-guaranteed loans than are government securities, that the demand for capital is more responsive to loan rates than to government security rates and that demand for the monetary base responds more to government security rates than to loan rates.
} 
generate lower loan rates to borrowers not receiving government assistance, higher interest rates on govermment securities and a higher demand price for capital.

These results can be seen intuitively by supposing that, in increasing direct loans, the government arbitrarily exchanges $\$ 1$ million of government securities for $\$ 1$ million of previously issued, governmentguaranteed loans in bank portfolios. Banks then find themselves with an excess supply of government securities and too few loans in their portfolios, which puts pressure on government security rates to rise and loan rates to uninsured borrowers to fall. The lower loan rates provide an incentive to households to purchase more capital and other commodities with borrowed funds so that either aggregate demand or the demand price of capital increases, or both.

Additional implications are that government budget deficits as currently measured may not accurately reflect the government's impact on the credit market and private capital expenditures; also, because government credit programs can change relative interest rates, any specific interest rate may be misleading as an indicator of financial market conditions. 